\title{
Foraging patterns of acorn woodpeckers (Melanerpes formicivorus) on valley oak (Quercus lobata Née) in two California oak savanna-woodlands
}

\author{
Douglas G. Scofield • Victor Ryan Alfaro • Victoria L. Sork • Delphine Grivet • \\ Edith Martinez · Jeannette Papp • Andrea R. Pluess • Walter D. Koenig • \\ Peter E. Smouse
}

Received: 25 March 2010/Accepted: 14 October 2010/Published online: 24 November 2010

(C) The Author(s) 2010. This article is published with open access at Springerlink.com

\begin{abstract}
Landscape characteristics and social behavior can affect the foraging patterns of seed-dependent animals. We examine the movement of acorns from valley oak (Quercus lobata) trees to granaries maintained by acorn woodpeckers (Melanerpes formicivorus) in two California oak savanna-woodlands differing in the distribution of Q. lobata within each site. In 2004, we sampled Q. lobata acorns from 16 granaries at Sedgwick Reserve in Santa Barbara County and 18 granaries at Hastings Reserve in Monterey County. Sedgwick has lower site-wide density of $Q$. lobata than Hastings as well as different frequencies of
\end{abstract}

Communicated by Scott Collins.

Electronic supplementary material The online version of this article (doi:10.1007/s00442-010-1828-5) contains supplementary material, which is available to authorized users.

D. G. Scofield $(\bowtie)$ V. R. Alfaro · V. L. Sork · D. Grivet ·

E. Martinez - A. R. Pluess

Department of Ecology and Evolutionary Biology,

University of California, 4139 Terasaki Life Sciences Building,

610 Charles E. Young Drive East, Los Angeles,

CA 90095-7239, USA

e-mail: douglasgscofield@gmail.com

\section{L. Sork}

Institute of the Environment, University of California,

Box 951496, Los Angeles, CA 90095-1496, USA

D. Grivet

Department of Forest Systems and Resources,

Forest Research Institute (CIFOR), National Institute

for Agriculture and Food Research and Technology (INIA),

Carretera de la Coruña km 7.5, 28040 Madrid, Spain

J. Papp

UCLA Genotyping and Sequencing Core, 5309 Gonda Center,

695 Charles Young Drive South, Los Angeles, CA 90095, USA other Quercus species common to both sites. We found acorn woodpeckers foraged from fewer $Q$. lobata seed source trees $\left(K_{\mathrm{g}}=4.1 \pm 0.5\right)$ at Sedgwick than at Hastings $\left(K_{\mathrm{g}}=7.6 \pm 0.6\right)$ and from fewer effective seed sources $\left(N_{\mathrm{em}} *=2.00\right.$ and 5.78, respectively). The differences between sites are due to a greater number of incidental seed sources used per granary at Hastings than at Sedgwick. We also found very low levels of seed source sharing between adjacent granaries, indicating that territoriality is strong at both sites and that each social group forages on its own subset of trees. We discovered an interesting spatial pattern in the location of granaries. At Sedgwick, acorn woodpeckers situated their granaries within areas of higher-thanaverage tree density, while at Hastings, they placed them within areas of lower-than-average tree density, with the outcome that granaries at the two sites were located in areas of similar valley oak density. Our results illustrate that

Present Address:

A. R. Pluess

Institute of Terrestrial Ecosystems, Swiss Federal Institute

of Technology (ETH), 8092 Zurich, Switzerland

W. D. Koenig

Lab of Ornithology, Cornell University,

159 Sapsucker Woods Road, Ithaca, NY 14850, USA

W. D. Koenig

Department of Neurobiology and Behavior, Cornell University, W263 Seeley G. Mudd Hall, Ithaca, NY 14853, USA

P. E. Smouse

Department of Ecology, Evolution and Natural Resources,

ENRS Building, Cook College, Rutgers University,

14 College Farm Road, New Brunswick, NJ 08901-8551, USA 
landscape characteristics might influence the number of trees visited by acorn woodpeckers and the locations of territories, while woodpecker social behavior, such as territoriality, shapes which trees are visited and whether they are shared with other social groups.

Keywords Acorn woodpecker - Foraging behavior . Habitat preferences - Probability of maternal identity (PMI) · UC Natural Reserve System

\section{Introduction}

Seed predators are common dispersal vectors for many tree species (van der Pijl 1982; Vander Wall 2010). Some vectors handle seeds in a manner more conducive to germination than do others (Briggs et al. 2009; Schupp 1993; Schupp et al. 2010), but regardless of the ultimate fate of the seeds, the pattern of seed transport reflects the foraging behavior of the vectors. Foraging behavior is affected by the distribution and abundance of seed resources and also by the foragers' social system (Johnson et al. 1997; Jordano et al. 2007). The acorn woodpecker (Melanerpes formicivorus) provides an ideal study system in which to examine the interaction between habitat structure and social and foraging behaviors (Koenig and Stacey 1990). This bird species has a highly stereotyped social system consisting of resident social groups that breed cooperatively and maintain territories surrounding acorn storage sites or 'granaries' (Koenig and Mumme 1987; Koenig et al. 1995). The North American acorn woodpecker's social group is dependent upon acorns for breeding success (Koenig and Mumme 1987) and constructs granaries by drilling hundreds to thousands of shallow holes into trees or other woody structures (Koenig and Mumme 1987; MacRoberts and MacRoberts 1976).

The foraging and social behaviors of acorn woodpeckers vary throughout their extensive range. Resident breeding populations are found from approximately $45^{\circ} \mathrm{N}$ at the Oregon-Washington border, extending south throughout California, and from Arizona and New Mexico, extending south through Mexico and Central America to approximately $2^{\circ} \mathrm{N}$ in the Andes of Colombia (Kattan 1988; Koenig et al. 1995; Winkler et al. 1995). In contrast to the behavior described above for California populations, however, the storage behavior of this woodpecker in tropical latitudes is more diverse, with some populations not storing food at all and others storing food in much smaller granaries or in other natural containers, such as bromeliads (Kattan 1988; Stacey 1981). In southeastern Arizona, where acorn availability is less reliable, some acorn woodpeckers forego the predominant social system altogether; these birds form temporary male-female breeding pairs, do not construct granaries, and migrate at the end of the breeding season. Just a few kilometers away, the same species forms typical cooperatively breeding bird groups that construct granaries and remain resident (Stacey and Bock 1978). These observations suggest that large-scale variation in habitat quality, particularly variation in food supply, can have a significant impact on the foraging, social, and food storage behaviors of the acorn woodpecker.

Given the range-wide variance in social organization and storage behavior, one might ask how much foraging behavior varies within and among sites having the same ecosystem type. Koenig and Mumme (1987) observed that the size of California acorn woodpecker groups would reduce to a single breeding pair during years of unusually low acorn availability. More generally, however, territories vary locally in quality, such that some have a higher constancy of tenancy (Koenig and Mumme 1987), a higher number of occupying adults, or a greater relative size of granary storage facilities (Stacey and Ligon 1987). This variation in territory quality may have accompanying effects on other behaviors, such as foraging patterns and territorial defense of seed resources. To date, the sole comparisons possible have relied upon data collected using quite different methods. In 2002, our lab collected acorns from granaries in an oak savanna-woodland ecosystem at Sedgwick Reserve, Santa Barbara County, California and inferred acorn woodpecker foraging patterns by matching acorns to acorn source trees using microsatellite genotypes of maternal tissues found in the acorns (Grivet et al. 2005). In that same year, Koenig et al. (2008) made direct behavioral observations of acorn woodpecker foraging bouts in the same type of ecosystem at Hastings Reserve, Carmel Valley, California, $240 \mathrm{~km}$ to the north. Direct behavioral observations enable the collection of detailed data on each foraging bout but carry the risk of a downward detection bias when estimating the number of trees visited, as foraging birds may fly long distances and can forage from trees located in unobserved directions (Koenig et al. 1996; Petit et al. 1989; Stone and Baker 1989). In contrast, our indirect genetic approach for monitoring foraging behavior foregoes behavioral details but enables the determination of the source tree for each acorn collected (Grivet et al. 2005). These disparate studies revealed that acorn woodpeckers foraged on similar numbers of $Q$. lobata seed source trees ( $K_{\mathrm{g}}=4.3$ vs. 5.8, Sedgwick vs. Hastings) and similar numbers of effective seed source trees $\left(N_{\mathrm{em}}=2.1\right.$ vs. 1.5 , respectively). It is tempting to conclude that the foraging behavior of acorn woodpeckers is similar at the two sites, but methodological differences as well as differences in site-wide density of $Q$. lobata at each site (lower at Sedgwick than at Hastings) place such a conclusion in doubt. Analysis of foraging behavior of woodpecker groups at these two sites using identical methods may help to unravel 
the effects of local habitat variation on the foraging and social behaviors of the acorn woodpecker.

In the study reported here, we utilized Grivet et al.'s (2005) genetic approach to assess the extent to which foraging behavior is similar at two oak savanna-woodland sites differing in tree density and composition. From past experience at both sites (Grivet et al. 2005; Koenig et al. 2008; Scofield et al. 2010), we anticipated that the social organization and territorial behavior of family groups should lead to a small number of local trees visited, with little overlap in the seed trees used by different territorial groups. At the same time, we also anticipated that differences in the density and spatial distribution of $Q$. lobata seed trees at the two sites could allow social groups to forage in more trees and with more relaxed territorial behavior at Hastings than at Sedgwick. We addressed three specific objectives. First, to evaluate whether acorn woodpecker foraging patterns differ between Sedgwick and Hastings, we estimated observed and effective numbers of seed sources used between different foraging groups at each site. Second, to determine the influence of territoriality on foraging, we estimated pair-wise overlap in seed source usage between granaries maintained by different social groups. Third, to evaluate how local tree density within a site might affect foraging, we documented overall tree density of $Q$. lobata trees at Sedgwick and Hastings Reserves in the vicinity immediately surrounding granaries and examined the relationship between the numbers of seed sources visited within each territory and the local density of $Q$. lobata immediately surrounding that granary.

\section{Materials and methods}

Study sites

Our study areas are located in central and southern coastal California, situated in the eastern foothills of the Coast Ranges, a Mediterranean ecosystem with geographically and ecologically diverse landscapes. In this region, oaks dominate most of the overstory of savannas, foothills, and riparian woodland and forest habitats. Our specific study sites include oak savanna and oak woodland ecosystems.

Sedgwick Reserve, our southern study site, is located in the Santa Ynez Valley in Santa Barbara County, CA, USA, $\left(34^{\circ} 40^{\prime} 52^{\prime \prime} \mathrm{N}, 120^{\circ} 02^{\prime} 24^{\prime \prime} \mathrm{W}\right)$ and is managed by UC Santa Barbara as part of the University of California Natural Reserve System (UC NRS). The central Figueroa Valley, where the study was located, encompasses an area of approximately 180 ha and consists of savanna and riparian woodlands dominated by valley oak ( $Q$. lobata), coast live oak ( $Q$. agrifolia), and blue oak ( $Q$. douglasii) (Tyler et al. 2006). Q. lobata is more or less evenly distributed in the valley (Fig. 1a).
Our second study site, the Hastings Natural History Reservation, is located $240 \mathrm{~km}$ north of Sedgwick Reserve, in Carmel Valley, Monterey County, CA $\left(36^{\circ} 22^{\prime} 42^{\prime \prime} \mathrm{N}\right.$ $\left.121^{\circ} 33^{\prime} 52^{\prime \prime} \mathrm{W}\right)$, and is managed by the UC Berkeley Museum of Vertebrate Zoology, also as part of the UC NRS. The Hastings Reserve contains diverse vegetation types, and the focal granaries are found in two separate locations within the reserve. A northern collection of 12 granaries were located within a 300-ha area at the northern edge of the Santa Lucia mountains, among Q. lobata stands that are unevenly distributed (Fig. 1b). Oak woodland and savannas in the valley and valley floor in this area are dominated by $Q$. douglasii (MacRoberts and MacRoberts 1976). The remaining six granaries sampled at Hastings were located within a 20-ha area $2-3 \mathrm{~km}$ south of the northern granaries, at a higher elevation within the Santa Lucia mountains where dense chaparral shrubs, black oak (Q. kellogii), and gray pine (Pinus sabiniana) are associated with $Q$. lobata and $Q$. douglasii woodlands.

\section{Study species}

In California, the acorn woodpecker (M. formicivorus) occupies a variety of habitats, such as foothill oak woodlands in the valleys and pine-oak forests in higher elevations and is a major transporter and consumer of acorns (Koenig and Haydock 1999; Koenig and Mumme 1987; MacRoberts and MacRoberts 1976). They forage in territorial, cooperatively breeding groups that contain up to 15 individuals of both sexes and all ages. Two to six individuals are breeders, while the rest are helpers that harvest acorns and defend their territories (Koenig and Mumme 1987; MacRoberts and MacRoberts 1976). We have already noted the dependence of acorn woodpeckers on acorns and their construction of granaries for storing acorns.

Valley oak (Q. lobata Née) is an endemic species distributed throughout the foothill oak woodlands and oak savannas of California (Griffin and Critchfield 1972; Pavlik et al. 1991). The species generally occurs on deep loamy soils below $600 \mathrm{~m}$ of elevation, with some populations ranging as high as 1,500 $\mathrm{m}$ (Sork et al. 2009).

\section{Sampling}

In 2004, we collected $Q$. lobata acorns from 16 granaries in Sedgwick (Fig. 1a) that were studied previously (Grivet et al. 2005). To ensure that we sampled acorns cached in 2004, we first marked an area approximately $0.5 \mathrm{~m}^{2}$ within each granary and removed all complete and partial acorns. We returned later to randomly sample newly cached acorns for this study. At Hastings, also in 2004, we sampled acorns from 23 granaries (Fig. 1c). In this site, we collected 
(a) Sedgwick Reserve

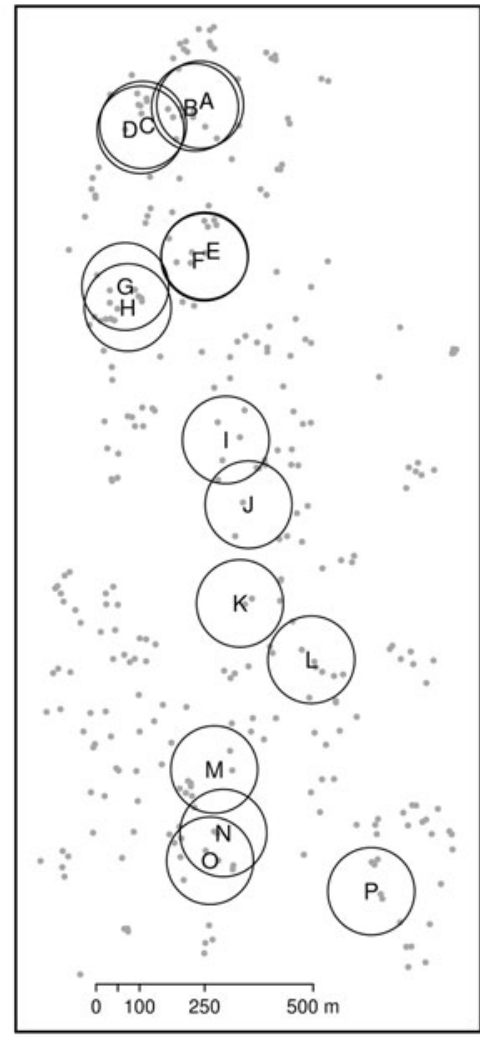

(c) Sedgwick Reserve

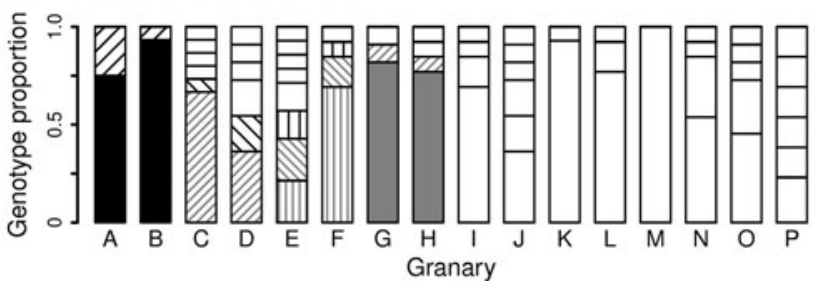

(b) Hastings Reserve

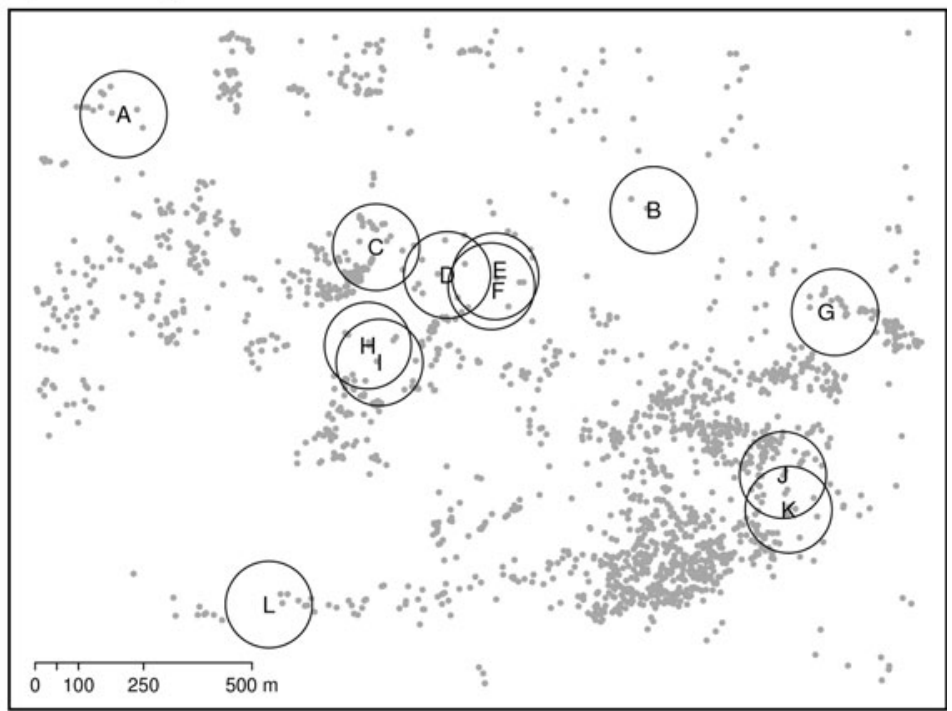

(d) Hastings Reserve

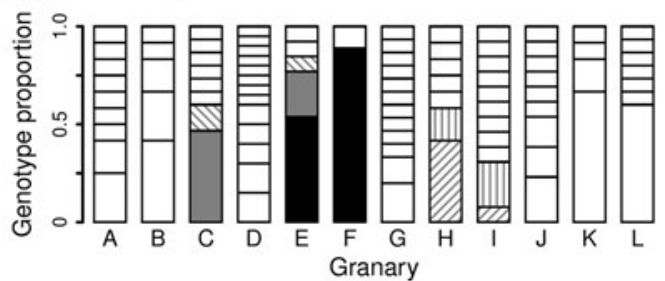

Fig. 1 Mapped locations of studied granaries and surrounding Quercus lobata adults at Sedgwick Reserve, Santa Barbara County, CA (a) and Hastings Reserve in Monterey County, CA (b). A 100-mradius circle circumscribes the area surrounding granaries (uppercase letters) to provide a scale for potential source trees. Dots Locations of Q. lobata individuals. $\mathbf{c}, \mathbf{d}$ Frequency of unique multilocus genotypes

acorns that were green and appeared fresh to avoid samples from previous years; the freshness of Hastings acorns was confirmed visually during tissue preparation. All tissues were cleaned and stored at $-80^{\circ} \mathrm{C}$ in a freezer immediately after collection.

We prepared maternal tissues by excising and grinding a portion of the maternally derived acorn pericarp (Godoy and Jordano 2001; Grivet et al. 2005; Ziegenhagen et al. 2003) with lysis buffer of the DNeasy Plant kit (QIAGEN, Hilden, Germany) and then followed the genotyping protocol described in Grivet et al. (2005). In preparing our PCRs, we did not dilute DNA extracts, which significantly of maternal source trees based on six microsatellite loci, in granaries at Sedgwick reserve (c) and Hastings reserve (d). Stacked histograms Frequency of maternal tissue genotypes among pericarps from that granary: white-filled segments pericarp genotypes unique to a single granary, grayscale and pattern-filled segments pericarp genotypes shared by two or more granaries

improved amplification. For our molecular analysis of acorn pericarp samples, we selected six microsatellite markers used by Grivet et al. (2005). PCR products were genotyped in the UCLA Genotyping and Sequencing Core (http://www.genoseq.ucla.edu).

\section{Statistical analysis}

For all genetic analyses, we used pericarp samples having complete six-locus genotypes with no missing alleles, and only included granaries with at least eight complete pericarp genotypes. At Sedgwick, the data set consisted of all 
16 granaries originally sampled, totaling $N=205$ pericarps with the number of pericarps per granary $\left(n_{\mathrm{g}}\right)=11-15$. At Hastings, we used 18 granaries (of 23 sampled) containing a total of $N=218$ pericarps, with $n_{\mathrm{g}}=8-20$.

We estimated the diversity of seed source usage using the probability of maternal identity (PMI) of seeds (Grivet et al. 2005; Scofield et al. 2010). PMI estimates the probability of two randomly sampled seeds from a specified granary sharing an identical maternal source tree. Three PMI estimators have been developed: (1) $q_{\mathrm{gg}}$, the standard maximum likelihood estimate; (2) $r_{\mathrm{gg}}$, which has a slightly larger variance but is unbiased; (3) $q_{\mathrm{gg}}{ }^{*}$ (Scofield et al. 2010), which adjusts $q_{\text {gg }}$ by a correction factor developed by Nielsen et al. (2003). The estimator $q_{\mathrm{gg}} *$ is less biased at a greater range of sample sizes and is more numerically stable than either of the other estimators. Here, we report $q_{\mathrm{gg}}{ }^{*}$, and include $r_{\mathrm{gg}}$ for comparison with $r_{\mathrm{gg}}$ estimates calculated by Koenig et al. (2008) from their behavioral observations. Regardless of the estimator used, at our smallest sample sizes, individual granary estimates can have large variance (Smouse and Robledo-Arnuncio 2005); thus, we prefer analyses that pool individual PMI estimates or which test overall trends.

The effective number of seed donors per granary $\left(N_{\mathrm{em}} *\right)$ represents the equivalent number of equally frequent seed sources producing the same probability of maternal identity and is the reciprocal of $q_{\mathrm{gg}} *$.

We quantified the overlap in seed source usage between granaries with a pairwise PMI analysis (Grivet et al. 2005; Scofield et al. 2010). The pairwise PMI estimate $q_{\mathrm{gh}}$ calculates the probability that one acorn drawn from each of two granaries $g$ and $h$ share the same acorn source tree, and is not biased. The pooled probability of maternal identity (PPMI) $q_{\mathrm{gh}}^{0}$ calculates the probability that two acorns drawn from granaries $g$ and $h$ are from any shared seed source (Scofield et al. 2010). PPMI will differ from (and be greater than) pairwise PMI whenever two granaries share seeds from two or more sources.

Equations for $q_{\mathrm{gg}}, r_{\mathrm{gg}}, q_{\mathrm{gg}}{ }^{*}, q_{\mathrm{gh}}$ and $q_{\mathrm{gh}}^{0}$ are available in the original papers, and equations to calculate their weighted means and variances are provided in the Electronic Supplementary Material (ESM). The weighted mean PMI estimates were compared between sites using $t$ tests for unequal sample sizes (Sokal and Rohlf 1995). All calculations were performed using the pmi functions written by D.G.S. for the R statistical system (R Development Core Team 2008) and are available at http://www.eeb.ucla.edu/ Faculty/Sork/Sorklab.

To estimate tree density, we characterized the distribution of $Q$. lobata around each granary in relation to the distribution of $Q$. lobata throughout the site, using a nearest-neighbor analysis. This analysis was based on the mapped locations of 1,005 adult trees at Sedgwick (V.L. Sork, F.W. Davis and P.E. Smouse, unpublished data), partially described in Dutech et al. (2005), and on 2,357 adult trees in the vicinity of the northern 12 granaries at Hastings (W.D. Koenig, unpublished data). We calculated the distance to the $k$ th nearest neighbor $(k-\mathrm{NN})$ for $k=1-15$, starting from each granary, and compared this distribution to a similar nearest-neighbor distribution calculated from each $Q$. lobata at the site. Because $95 \%$ of acorn woodpecker foraging bouts occur within $150 \mathrm{~m}$ of a granary (Grivet et al. 2005; Koenig et al. 2008; Scofield et al. 2010), we confined the trees used to construct this latter distribution to those $Q$. lobata having at least one conspecific neighbor within $150 \mathrm{~m}$. At Sedgwick, nearestneighbor distributions calculated using all 33 known granaries are quantitatively very similar to those for the 16 sampled granaries used here (Pearson's $r=0.999$, $\left.t=75.48, d f=13, P=7 \times 10^{-19}\right)$.

\section{Results}

Acorn woodpecker foraging patterns differed between sites in that acorn woodpeckers used a lower number of seed sources at Sedgwick than at Hastings Reserves; this finding was apparent in all measures of seed source usage. In general, at Hastings in comparison to Sedgwick, woodpecker groups used about twofold more observed seed sources per granary, with wide variance in the number of seed sources from granary to granary, and they foraged on about threefold more effective seed sources per granary. At Sedgwick, we found 57 unique maternal genotypes among 205 seeds, while at Hastings, we found 128 unique maternal genotypes among 218 seeds. The number of seed sources observed within individual granaries $\left(K_{\mathrm{g}}\right)$ ranged from one to eight at Sedgwick [mean \pm standard error $(\mathrm{SE})=4.1 \pm 0.5]$ and from two to 13 at Hastings $(7.6 \pm 0.6)$ (Table 1). PMI estimates of the effective number of seed sources varied among individual granaries at both sites, ranging from 1.0 to 10.2 at Sedgwick, and from 1.3 to 28.0 at Hastings (Table 1 ). The coefficient of variation among PMI estimates $\left(\mathrm{CV}=\sqrt{\sigma_{q^{*}}^{2}} / \bar{q}_{0}^{*}\right)$ was lower at Sedgwick (0.571) than at Hastings (0.960). The weighted mean PMI estimates $\left[\bar{q}_{0}^{*}\right.$, Eq. (ESM4) in the Electronic Supplementary Materials] were $\bar{q}_{0}^{*} \pm \mathrm{SE}=$ $0.500 \pm 0.071$ at Sedgwick and $0.173 \pm 0.039$ at Hastings, and this difference was significant $(t=-4.14, d f=32$, $\left.P=2.4 \times 10^{-4}\right)$. A similar relationship was observed with the $\bar{r}_{0}$ estimator of Eq. (ESM5) in the Electronic Supplementary Materials $\left(\bar{r}_{0} \pm \mathrm{SE}=0.493 \pm 0.072\right.$ vs. $\left.0.161 \pm 0.039 ; \quad t=-4.16, \quad d f=32, \quad P=2.2 \times 10^{-4}\right)$. 
Table 1 Probability of maternal identity estimates for granaries in the Sedgwick and Hastings Reserves, respectively, with at least eight pericarps having complete six-locus genotypes

\begin{tabular}{|c|c|c|c|c|c|}
\hline Granary ID $^{\mathrm{a}}$ & $n_{\mathrm{g}}$ & $K_{\mathrm{g}}$ & $q_{\mathrm{gg}}^{*}$ & $N_{\mathrm{em}}^{*}$ & $r_{\mathrm{gg}}$ \\
\hline \multicolumn{6}{|l|}{ Sedgwick reserve } \\
\hline A & 12 & 2 & 0.597 & 1.7 & 0.591 \\
\hline B & 15 & 2 & 0.868 & 1.2 & 0.867 \\
\hline $\mathrm{C}$ & 15 & 6 & 0.434 & 2.3 & 0.429 \\
\hline $\mathrm{D}$ & 11 & 6 & 0.161 & 6.2 & 0.145 \\
\hline $\mathrm{E}$ & 14 & 8 & 0.098 & 10.2 & 0.088 \\
\hline $\mathrm{F}$ & 13 & 4 & 0.481 & 2.1 & 0.474 \\
\hline G & 11 & 3 & 0.661 & 1.5 & 0.655 \\
\hline $\mathrm{H}$ & 13 & 4 & 0.582 & 1.7 & 0.577 \\
\hline I & 13 & 4 & 0.481 & 2.1 & 0.474 \\
\hline $\mathrm{J}$ & 11 & 6 & 0.161 & 6.2 & 0.145 \\
\hline $\mathrm{K}$ & 14 & 2 & 0.859 & 1.2 & 0.857 \\
\hline $\mathrm{L}$ & 13 & 3 & 0.595 & 1.7 & 0.590 \\
\hline $\mathrm{M}$ & 13 & 1 & 1.000 & 1.0 & 1.000 \\
\hline $\mathrm{N}$ & 13 & 4 & 0.355 & 2.8 & 0.346 \\
\hline $\mathrm{O}$ & 11 & 5 & 0.250 & 4.0 & 0.236 \\
\hline \multirow[t]{2}{*}{$\mathrm{P}$} & 13 & 6 & 0.114 & 8.8 & 0.103 \\
\hline & & & $\bar{q}_{0}^{*} \pm \mathrm{SE}$ & & $\bar{r}_{0} \pm \mathrm{SE}$ \\
\hline Weighted mean $\pm \mathrm{SE}$ & 205 & $4.1 \pm 0.5$ & $0.500 \pm 0.071$ & 2.00 & $0.493 \pm 0.072$ \\
\hline \multicolumn{6}{|l|}{ Hastings reserve } \\
\hline A & 12 & 9 & 0.075 & 13.4 & 0.061 \\
\hline $\mathrm{B}$ & 12 & 5 & 0.224 & 4.5 & 0.212 \\
\hline $\mathrm{C}$ & 15 & 8 & 0.217 & 4.6 & 0.210 \\
\hline $\mathrm{D}$ & 20 & 13 & 0.052 & 19.1 & 0.047 \\
\hline$E^{1}$ & 13 & 5 & 0.317 & 3.2 & 0.308 \\
\hline $\mathrm{F}^{1}$ & 9 & 2 & 0.784 & 1.3 & 0.778 \\
\hline G & 15 & 12 & 0.047 & 21.2 & 0.038 \\
\hline $\mathrm{H}^{2}$ & 12 & 7 & 0.179 & 5.6 & 0.167 \\
\hline $\mathrm{I}^{2}$ & 13 & 11 & 0.051 & 19.7 & 0.038 \\
\hline $\mathrm{J}^{3}$ & 13 & 9 & 0.076 & 13.1 & 0.064 \\
\hline $\mathrm{K}^{3}$ & 12 & 4 & 0.448 & 2.2 & 0.439 \\
\hline $\mathrm{L}^{\mathrm{b}}$ & 15 & 7 & 0.349 & 2.9 & 0.343 \\
\hline $104^{\mathrm{c}, 4}$ & 11 & 7 & 0.125 & 8.0 & 0.109 \\
\hline $105^{\mathrm{c}, 4}$ & 9 & 8 & 0.055 & 18.3 & 0.028 \\
\hline $106^{\mathrm{c}}$ & 12 & 8 & 0.120 & 8.4 & 0.106 \\
\hline $108^{\mathrm{c}}$ & 8 & 8 & 0.036 & 28.0 & 0.000 \\
\hline $110^{\mathrm{c}}$ & 9 & 6 & 0.136 & 7.4 & 0.111 \\
\hline \multirow[t]{2}{*}{$111^{\mathrm{c}}$} & 8 & 8 & 0.036 & 28.0 & 0.000 \\
\hline & & & $\bar{q}_{0}^{*} \pm \mathrm{SE}$ & & $\bar{r}_{0} \pm \mathrm{SE}$ \\
\hline Weighted mean $\pm \mathrm{SE}$ & 218 & $7.6 \pm 0.6$ & $0.173 \pm 0.039$ & 5.78 & $0.161 \pm 0.039$ \\
\hline
\end{tabular}

$n_{\mathrm{g}}$, Number of pericarps; $K_{\mathrm{g}}$, number of unique seed sources; $q_{\mathrm{gg}}^{*}$ and $r_{\mathrm{gg}}$, the estimated probability of maternal identity (PMI); $N_{\mathrm{em}}^{*}$, the effective number of seed sources calculated as the reciprocal of $q_{\mathrm{gg}}^{*}$ and the number of trees in proximity to each granary; SE, standard error

${ }^{\text {a }}$ Granaries with the same superscript number $(1,2,3$, or 4) are maintained by the same bird group, as determined by direct behavioral observations (W. D. Koenig, unpublished data)

b This granary is constructed in the trunk of Platanus racemosa

c These granaries on the isolated southerly area of Hastings were not included in analyses of habitat variation because adult $Q$. lobata in the vicinity were not mapped 
The reciprocal of the PMI estimate $\bar{q}_{0}^{*}$ gave an average effective number of maternal seed sources of $N_{\mathrm{em}} *=2.00$ at Sedgwick and $N_{\mathrm{em}} *=5.78$ at Hastings. On average, a given woodpecker social group foraged from almost threefold more effective seed sources at Hastings than at Sedgwick.

To understand the effect that site may have on territoriality, we estimated the overlap in seed source usage among granaries using pairwise PMI $\left(q_{\mathrm{gh}}\right)$ and PPMI $\left(q_{\mathrm{gh}}^{0}\right)$. In general, we found little evidence of overlap in seed source usage, with the exception of four pairs of granaries at Sedgwick (Table 2, Sedgwick Reserve; Fig. 1b), and six pairs of granaries at Hastings (Table 2, Hastings Reserve; Fig. 2d). One pair of granaries at Hastings $(\mathrm{J} / \mathrm{K})$ tended by the same bird group (W.D. Koenig, personal observation) showed no seed source sharing using our methods (Table 2, Hastings Reserve). Among all possible granary pairs, Sedgwick had slightly higher pairwise mean seed source sharing $\left(\bar{q}_{\mathrm{gh}}=0.015 \pm 0.0083\right.$ among 120 pairs) than Hastings $\left(\bar{q}_{\mathrm{gh}}=0.0042 \pm 0.0029\right.$ among 153 pairs), but neither value was very large and neither mean was significantly different from 0 (Table 2). Among pairs of granaries in which seed source sharing occurred, it was generally higher at Sedgwick than at Hastings. The weighted mean pairwise PMI among the four granary pairs putatively shared by the same bird group at Sedgwick $(0.443 \pm 0.134)$ was higher than that among the four granary pairs known to be shared by the same bird group at
Hastings $(0.133 \pm 0.108)$, a difference that was marginally significant for PMI $(t=1.8007, d f=6, P=0.061)$ and significant for PPMI among these same granaries $(t=2.9011, d f=6, P=0.027)$. This difference is not due to a lower mean distance separating granaries of each pair at Sedgwick vs. Hastings because the mean distances separating these particular pairs at each site did not differ (Table $2 ; t=1.1613, d f=6, P=0.29$ ), although overall average distance between sampled granaries was significantly greater at Sedgwick than Hastings (Table 2). At both sites, acorn woodpecker social groups were highly territorial and foraged from non-overlapping sets of $Q$. lobata seed source trees.

To understand how adult tree density might affect foraging, our third objective was to analyze tree density at the two sites. The site-wide density of $Q$. lobata was higher at Hastings than at Sedgwick, as indicated by the mean $k$-NN distances from all $Q$. lobata trees being about half as long at Hastings as at Sedgwick (Fig. 2a, open circles). Despite this difference in site-wide tree density, $k$-NN distances to $Q$. lobata from granaries were similar at the two sites, indicating that granaries were located in areas with similar tree density at both sites (Fig. 2a, filled triangles). A closer look at site-specific patterns showed that granaries at Hastings were located in areas with a lower tree density than the site-wide mean density (Fig. 2b, open inverted triangles) while, in contrast, granaries at Sedgwick were located in areas with higher tree
Table 2 Summary of pairwise PMI $\left(q_{\mathrm{gh}}\right)$ and pooled (P)PMI $\left(q_{\mathrm{gh}}^{0}\right)$ values across pairs of granaries sharing either seed sources or tended by the same bird group (W.D. Koenig, unpublished data), mean pairwise PMI for any pair of granaries within each site $\left(\bar{q}_{\mathrm{gh}}\right)$, distances separating granaries of each pair, and the mean distance from a granary to the next nearest granary at each site

\begin{tabular}{|c|c|c|c|c|c|}
\hline Granary pair & Bird group & $q_{g h}$ & $q_{\mathrm{gh}}^{0}$ & Pooled $q_{\mathrm{gg}}^{*}$ & Distance between granaries $(\mathrm{m})$ \\
\hline \multicolumn{6}{|c|}{ Sedgwick reserve } \\
\hline $\mathrm{A}, \mathrm{B}$ & & 0.717 & 1.000 & 0.739 & 13.1 \\
\hline $\mathrm{G}, \mathrm{H}$ & & 0.636 & 0.769 & 0.625 & 48.3 \\
\hline $\mathrm{C}, \mathrm{D}$ & & 0.255 & 0.400 & 0.294 & 12.2 \\
\hline \multirow[t]{2}{*}{$\mathrm{E}, \mathrm{F}$} & & 0.192 & 0.527 & 0.230 & 3.3 \\
\hline & & \multicolumn{3}{|c|}{$\bar{q}_{\mathrm{gh}}=0.015 \pm 0.0083$} & $\begin{array}{l}96.2 \pm 25.7 \text { mean to } \\
\text { nearest granary }\end{array}$ \\
\hline \multicolumn{6}{|c|}{ Hastings reserve } \\
\hline $\mathrm{E}, \mathrm{F}$ & Dipsy & 0.479 & 0.479 & 0.470 & 24.7 \\
\hline $\mathrm{H}, \mathrm{I}$ & Lower Haystack & 0.071 & 0.179 & 0.086 & 47.4 \\
\hline $\mathrm{J}, \mathrm{K}$ & School Hill & 0.000 & 0.000 & 0.116 & 81.0 \\
\hline 104,105 & Lambert & 0.030 & 0.091 & 0.058 & 9.5 \\
\hline $\mathrm{C}, \mathrm{E}$ & Soto Springs $\left.{ }^{\odot}\right)$, Dipsy (E) & 0.118 & 0.185 & - & 283.0 \\
\hline 104,110 & Lambert (104), unknown (110) & 0.010 & 0.010 & - & 625.3 \\
\hline \multirow[t]{2}{*}{105,110} & Lambert (105), unknown (110) & 0.012 & 0.012 & - & 627.6 \\
\hline & & \multicolumn{3}{|c|}{$\bar{q}_{\mathrm{gh}}=0.0042 \pm 0.0029$} & $\begin{array}{l}184.7 \pm 48.1 \text { mean to } \\
\text { nearest granary }\end{array}$ \\
\hline
\end{tabular}




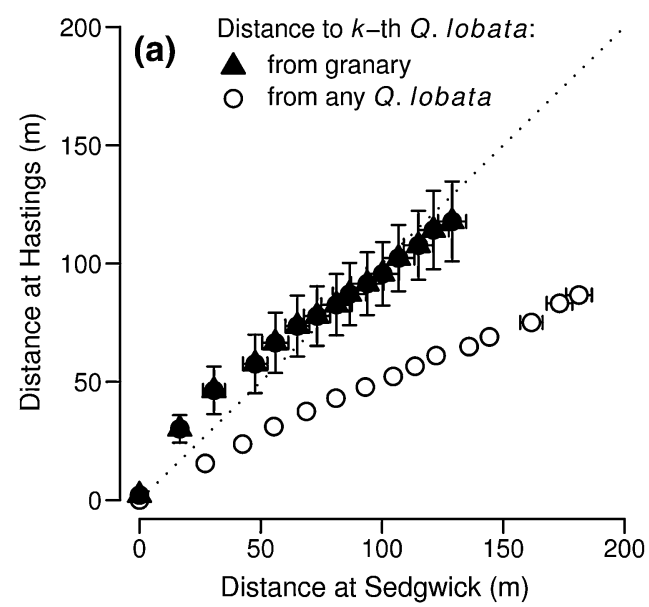

Fig. 2 Nearest-neighbor analysis of $Q$. lobata spatial distributions surrounding granaries and throughout each site. Shown are mean distances $\pm \mathrm{SE}$ to the $k$-th nearest neighbors $(k$-NN, for $k=1-15)$ starting from either a granary or any mapped $Q$. lobata within the site (see text). The diagonal line in each panel indicates equivalent

density than the site-wide mean density (Fig. 2b, filled squares). We found that site (Sedgwick vs. Hastings) was a significant factor determining differences in seed source number $\left(K_{\mathrm{g}}: F_{1,26}=12.52, P=0.0015 ; N_{\mathrm{em}} *: F_{1,26}=\right.$ 7.986, $P=0.0089$ ). We could find no effect of local densities of $Q$. lobata on the number of seed sources within individual granaries (regressions of $K_{\mathrm{g}}$ and $N_{\mathrm{em}}{ }^{*}$ vs. number of trees within 50,100 and $150 \mathrm{~m}$ of the granary; results not shown).

\section{Discussion}

The effects of seed source density

As we had initially expected, the number of $Q$. lobata seed sources used by acorn woodpeckers is higher at the site with higher tree density (Hastings). However, this result now seems incongruous with our finding that acorn woodpeckers locate their granaries at each site such that surrounding densities of Q. lobata are similar (Fig. 2). Similar densities of seed sources surrounding the granaries of this territorial species should result in similar foraging patterns at the two sites. Instead, at Hastings, birds forage from a greater number of incidental (low frequency) seed sources (Fig. 1b vs. d), which is largely responsible for the differences in the effective number of seed sources $\left(N_{\mathrm{em}}{ }^{*}\right)$ observed between sites. The alternative, that acorn woodpeckers forage from a more evenly distributed set of more numerous seed sources at Hastings, is not reflected in our data. Given the woodpeckers' preference at each site for locating granaries in areas with similar $Q$. lobata densities,

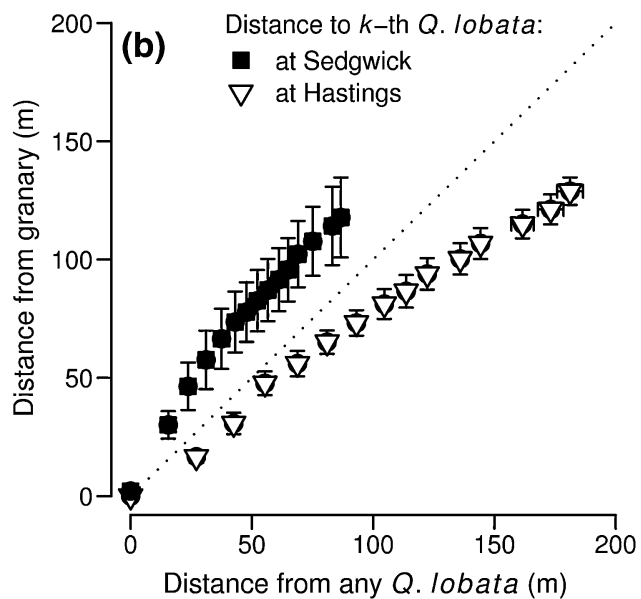

distances along each axis. a Hastings vs. Sedgwick $k$-NN distances from granaries (filled triangles) and from any $Q$. lobata (open circles). b $k$-NN distances from granaries vs. from any $Q$. lobata at Sedgwick (filled squares) and Hastings (open inverted triangles)

site-wide differences in tree density may be more apparent at the spatial limits of territories, such that at Hastings acorn woodpeckers have a greater number of seed sources to choose from while foraging at territorial edges. The sitewide difference in tree density may also be reflected in lower overall seed source overlap between granaries at Hastings vs. Sedgwick, in that there is a greater availability of seed sources at less well-defended peripheries of territories. We do not have microsatellite genotypes for adult Q. lobata surrounding granaries at Hastings, so we cannot subject this hypothesis to further testing.

Territorial foraging at both sites

One element of woodpecker behavior that is strikingly similar between Sedgwick and Hastings is the high degree of territoriality, as revealed by the minimal overlap in acorn source tree usage among granaries defended by different bird groups (Table 2). In this aspect, our observations are also fully compatible with those of Koenig et al. (2008). For granaries known, or assumed, to be tended by the same bird group, patterns are qualitatively similar between sites. Granaries with overlapping foraging radii at both sites showed similar patterns (Fig. 1; Table 2). Acorn trees that are found in two granaries are often adjacent granaries used by the same woodpecker group. However, this is not always the case. The Hastings $\mathrm{J} / \mathrm{K}$ granaries are maintained by the same bird group as determined from behavioral observations (Table 2, Hastings Reserve) and have overlapping radii (Fig. 1c), but they showed no shared acorn sources $\left(r_{\mathrm{gh}}=0\right)$. In contrast, our indirect genetic data also indicates occasional incidents where acorns from 
the same trees were shared between widely separated granaries at Hastings (Table 2, Hastings Reserve: C/E, 104/ $110,105 / 110)$. Such extraterritorial foraging may have occurred due to the non-saturated spatial array of woodpecker territories (Koenig and Mumme 1987; Koenig et al. 1996) and would be both unlikely to occur between adjacent occupied territories and difficult to observe directly.

Behavioral versus genetic methods for observing foraging and social behaviors

Additional insight into foraging behavior may be gained by contrasting behavioral observations with genetic seedbased observations from the same site and year. In their own comparisons, Koenig et al. (2008) found their behaviorally based PMI estimate to be quantitatively similar to a genetic PMI estimate from Sedgwick in 2002 (Grivet et al. 2005). In this study, our own PMI estimate at Sedgwick in 2004 (Table 1, $\bar{r}_{0}=0.493$ ) is similar to the 2002 estimate $\left(\bar{r}_{0}=0.474\right)$, but genetic estimates of PMI from 2004 are not similar between Hastings and Sedgwick estimates from 2004. Moreover, our 2004 genetic PMI estimate from Hastings is not similar to the behaviorally based PMI estimate of Koenig et al. (2008) at Hastings in 2004. The genetic estimates indicate more seed sources per granary $\left(K_{\mathrm{g}}\right)$ and a greater effective number of seed sources $\left(N_{\mathrm{em}}\right.$, based on $\left.\bar{r}_{0}\right)$ than behavioral methods. Specifically, we found $K_{g}=7.6 \pm 0.6$ and $\bar{r}_{0}=0.161 \pm 0.039$ per granary (Table 1), giving an $N_{\mathrm{em}}=6.21$ (based on $\bar{r}_{0}$ ), while Koenig et al. (2008) observed $K_{\mathrm{g}}=5.8$ and $\bar{r}_{0}=$ 0.541 per granary (no SEs reported), giving $N_{\mathrm{em}}=1.85$. We also observed a greater degree of seed source sharing than did Koenig et al. (2008). In their study, they examined the sharing of seed sources between adjacent territories tended by three different bird groups; therefore, we restricted our analysis to granaries known or suspected to be maintained by different bird groups (C/E, 104/110, and 105/110 in Table 2, Hastings Reserve). With this restricted data set, we observed seed source sharing at Hastings (weighted mean $\bar{q}_{\mathrm{gh}}=0.067 \pm 0.039, n=3$ ), while Koenig et al. (2008) observed no sharing of sources in 2004 $\left(\bar{q}_{\mathrm{gh}}=0\right)$ and in other years observed no sharing or very low sharing of sources between these same territories (mean of $\bar{q}_{\mathrm{gh}}=0.001$ across four study years). This reduced observation of rare events occurred despite Koenig et al. directly recording over 2.6-fold as many dispersal events as did we in 2004 (579 vs. 218).

These differences indicate detection differences inherent in the methods themselves. In many field settings, direct foraging observations would underestimate $N_{\mathrm{em}}$ due to difficulties in ensuring that seeds arriving from sources located at any direction and from any distance are equally likely to be observed. Genetic methods, however, integrate across foraging bouts by the woodpeckers (Grivet et al. 2005; Scofield et al. 2010). These differences are further underscored by noting that the mean $N_{\mathrm{em}}$ of our four leastdiverse granaries at Hastings is still greater than that observed by Koenig et al. (2008). Many details of foraging and social behavior of acorn woodpeckers have been established using direct behavioral observations. Our comparisons here emphasize the importance of including less common events and show that seed source diversity is best quantified by combining behavioral observations with indirect genetic methods. Ideally, one would couple behavioral and genetic observations of the same granaries.

\section{Conclusions}

Habitat variation affects the foraging behavior of acorn woodpeckers, such that increased tree density at a site increases the observed and effective numbers of seed sources sampled by the woodpeckers at any particular granary. However, bird groups choose territories having broadly similar densities of trees surrounding granaries regardless of site-wide tree density. Generally, relatively few trees are visited by any particular social group, and this number is largely independent of the number of potential seed sources available within the territory. Details aside, territorial behavior is similar between sites with strong limits on the shared use of acorn source trees among foraging groups. This study system provides strong evidence that habitat variation can affect the details of foraging behavior, but the social system itself shapes patterns of seed source usage.

Acknowledgments The authors thank Mike Williams, Kate McCurty, and the staff of the UC Santa Barbara Sedgwick Reserve and Mark Stromberg and staff of the UC Berkeley Hastings Natural History Reservation for logistical support. For technical assistance, we thank Karen Lundy from the Sork lab and Sugandha Dandekar from the UCLA Genotyping and Sequencing facility. We thank Scott Collins, Jacqui Shykoff, and four anonymous reviewers for comments which greatly improved earlier versions of this manuscript. V.R.A. was supported by an REU supplement to NSF-DEB-0516529. D.G.S., V.L.S., D.G., and A.R.P. acknowledge the support of the National Science Foundation (NSF-DEB-0516529) and UCLA. W.D.K. was supported by NSF-IOB-0516851. P.E.S. received funding from the US Department of Agriculture and the New Jersey Agricultural Experiment Station (USDA/NJAES-17111) and from the National Science Foundation (NSF-DEB-0514956). This work was performed (in part) at the University of California Natural Reserve System Sedgwick and Hastings Reserves. The experiments presented here comply with the current laws of the United States of America.

Open Access This article is distributed under the terms of the Creative Commons Attribution Noncommercial License which permits any noncommercial use, distribution, and reproduction in any medium, provided the original author(s) and source are credited. 


\section{References}

Briggs JS, Vander Wall SB, Jenkins SH (2009) Forest rodents provide directed dispersal of Jeffrey pine seeds. Ecology 90:675-687

Dutech C, Sork VL, Irwin AJ, Smouse PE, Davis FW (2005) Gene flow and fine-scale genetic structure in a wind-pollinated tree species Quercus lobata (Fagaceae). Am J Bot 92:252-261

Godoy JA, Jordano P (2001) Seed dispersal by animals: exact identification of source trees with endocarp DNA microsatellites. Mol Ecol 10:2275-2283

Griffin JR, Critchfield WB (1972) The distribution of forest trees in California. US Forest Service Research Paper PSW 82:1-114

Grivet D, Smouse PE, Sork VL (2005) A novel approach to an old problem: tracking dispersed seeds. Mol Ecol 14:3585-3595

Johnson WC, Adkisson CS, Crow TR, Dixon MD (1997) Nut caching by blue jays (Cyanocitta cristata L.): implications for tree demography. Am Midl Nat 138:357-370

Jordano P, Garcia C, Godoy JA, Garcia-Castano JL (2007) Differential contribution of frugivores to complex seed dispersal patterns. Proc Natl Acad Sci USA 104:3278-3282

Kattan G (1988) Food habits and social organization of acorn woodpeckers in Colombia. Condor 90:100-106

Koenig WD, Haydock J (1999) Oaks, acorns, and the geographical ecology of acorn woodpeckers. J Biogeogr 26:159-165

Koenig WD, Mumme RD (1987) Population ecology of the cooperatively breeding acorn woodpecker. Princeton University Press, Princeton

Koenig WD, Stacey PB (1990) Acorn woodpeckers: group-living and food storage under contrasting ecological conditions. In: Stacey PB, Koenig WD (eds) Cooperative breeding in birds. Cambridge University Press, Cambridge, pp 415-453

Koenig WD, Stacey PB, Stanback MT, Mumme RL (1995) Acorn woodpecker. Birds North Am 194:1-24

Koenig WD, Van Vuren D, Hooge PN (1996) Detectability, philopatry, and the distribution of dispersal distances in vertebrates. Trends Ecol Evol 11:514-517

Koenig WD, McEntee JP, Walters EL (2008) Acorn harvesting by acorn woodpeckers: annual variation and comparisons with genetic markers. Evol Ecol Res 10:811-822

MacRoberts MH, MacRoberts BR (1976) Social organization and behavior of the acorn woodpecker in central coastal California. Ornithol Monog 21:1-115

Nielsen R, Tarpy DR, Reeve HK (2003) Estimating effective paternity number in social insects and the effective number of alleles in a population. Mol Ecol 12:3157-3164

Pavlik BM, Muick PC, Johnson SG, Popper M (1991) Oaks of California. California Press/California Oak Foundation, Los Olivos
Petit DR, Petit LJ, Petit KE (1989) Winter caching ecology of deciduous woodland birds and adaptations for protection of stored food. Condor 91:766-776

R Development Core Team (2008) R: A language and environment for statistical computing. R Foundation for Statistical Computing, Vienna

Schupp EW (1993) Quantity, quality and the effectiveness of seed dispersal by animals. Vegetatio 107(108):15-29

Schupp EW, Jordano P, Gómez JM (2010) Seed dispersal effectiveness revisited: a conceptual review. New Phytol 188:333-353

Scofield DG, Sork VL, Smouse PE (2010) Influence of acorn woodpecker social behaviour on transport of coast live oak (Quercus agrifolia) acorns in a southern California oak savanna. J Ecol 98:561-572

Smouse PE, Robledo-Arnuncio JJ (2005) Measuring the genetic structure of the pollen pool as the probability of paternal identity. Heredity 94:640-649

Sokal RR, Rohlf FJ (1995) Biometry, 3rd edn. W. H. Freeman, New York

Sork VL, Davis FW, Grivet D (2009) Incorporating genetic information into conservation planning for California valley oak. In: Merenlender A, McCreary D, Purcell KL (eds) Proceedings of the 6th symposium on Oak Woodlands: California's Oaks: today's challenges, tomorrow's opportunities. Gen. Tech. Rep. PSW-GTR-217. Pacific Southwest Research Station, Forest Service, US Department of Agriculture, Albany, pp 497-509

Stacey PB (1981) Foraging behavior of the acorn woodpecker in Belize, Central America. Condor 83:336-339

Stacey PB, Bock CE (1978) Social plasticity in the Acorn Woodpecker. Science 202:1298-1300

Stacey PB, Ligon JD (1987) Territory quality and dispersal options in the acorn woodpecker, and a challenge to the habitat-saturation model of cooperative breeding. Am Nat 130:654-676

Stone ER, Baker MC (1989) The effects of conspecifics on food caching by Black-Capped Chickadees. Condor 91:886-890

Tyler CM, Kuhn B, Davis FW (2006) Demography and recruitment limitations of three oak species in California. Q Rev Biol $81: 127-152$

van der Pijl L (1982) Principles of dispersal in higher plants, 3rd edn. Springer, Berlin

Vander Wall SB (2010) How plants manipulate the scatter-hoarding behaviour of seed-dispersing animals. Philos T Roy Soc B 365: 989-997

Winkler H, Christie DA, Nurney D (1995) Woodpeckers: an identification guide to the woodpeckers of the world. Houghton Mifflin, Boston

Ziegenhagen B, Liepelt S, Kuhlenkamp V, Fladung M (2003) Molecular identification of individual oak and fir trees from maternal tissues of their fruits or seeds. Trees-Struct Funct $17: 345-350$ 